\title{
Examining the Efficiency of Zakat Management: Indonesian Zakat Institutions Experiences
}

\author{
Solahuddin Al-Ayubi \\ STEI TAZKIA
}

Ascarya

Central Bank of Indonesia

\section{Bayu Taufiq Possumah \\ STEI TAZKIA}

\begin{abstract}
This study evaluates the efficiency of Indonesian Zakat Institutions (IZI), including technical, pure technical and scale efficiencies using a production approach. This study also examines the sources of inefficiency. By employing the Data Envelopment Analysis (DEA) technique, this study proposes a solution to improving the efficiency of IZI. The input variables of this study are the number of amil, the number of volunteers, the number of offices, socialization costs, personnel costs, and operational costs. The output variables of this study include the amount of zakat collected, the distribution of consumptive zakat, the distribution of productive zakat, the number of muzakki and the number of mustahiq.

The results indicate that between 2010-2013 IZI Mass technical efficiency were higher than IZI Non-Mass on average. In 2014, IZI Non-Mass exceeded IZI Mass technical efficiency. IZI Mass pure technical efficiency had an upward trend during 2011-2013, but then declined during 2014-2016. However, IZI Non-Mass pure technical efficiency experienced an upward trend during 2011-2012, then slightly decreased in 2013. Although the efficiency increased in 2014-2015, there was a subsequent decrease in 2016. After a period of fluctuation during 2011-2013, the scale efficiency of IZI Mass decreased in 2014 and stabilized in 2015-2016. Similarly, IZI Non-Mass fluctuated during 2011-2012, then stabilizing until 2016.

The increasing problems of IZI Mass and IZI Non-Mass are the socialization costs, the number of volunteers, the amount of zakat collected, and the distribution of consumptive zakat, which cumulatively reduces the intermediation function of zakat institutions. IZI must resolve these issues to ameliorate the efficiency of zakat institutions.
\end{abstract}

Keywords: Indonesian Zakat Institutions, Efficiency, Technical Efficiency

JEL Classification Code: L31, D61

\section{INTRODUCTION}

Zakat is one of the five pillars of Islam. It is an obligation of Muslims to donate a specific amount of their wealth to the beneficiaries with the main objective of achieving socioeconomic justice (Wahab dan Rahma, 2011:1).

The Zakat collection system in Indonesia is managed voluntarily. Since it is not a liability under Indonesian law, 
zakat collection in Indonesia is far beneath its potential (Beik et al., 2014: 10).

According to BAZNAS (2017: 6), zakat funds collected by OPZ in 2015 amounted to IDR 3.7 trillion, which is less than 1.3 per cent of its total potential. The gap between the potential and realization of zakat funds collection is an on-going issue faced by zakat institutions. Zakat regulation in Indonesia is under the 2011 Zakat Act No. 23, which brought all major private zakat collectors under the supervision of the National Board of Zakat (BAZNAS). Yet, the Act does not utterly support the operations of Zakat institutions, nor does it live up to expectations. This is evidenced by the incomplete reporting of zakat funds collection, which demonstrate a feeble depiction of overall data of Indonesian zakat Institutions (IZI) (PUSKAS BAZNAS, 2017: 7).

Jahar (2010:1) maintains that trust and professionalism are vital to supporting the development of zakat institutions. Today's organizations are facing challenges that require effective management decisions that will achieve high levels of productivity and efficiency (Wahab, 2013: 1). Likewise, Beik et al. (2014: 28-29) state that in their operation, zakat institutions are responsible for upholding certain basic principles, such as professionalism, accountability and transparency. Moreover, the management of zakat institutions must be effective and efficient.

The gap between the potential and realization of zakat funds collection is caused by the lack community trust of zakat institutions. A measurement of zakat management and efficiency of zakat institutions may rectify public mistrust (Lessy, 2009: 106).

This study analyses the technical efficiency and technical issues (including the scale) of Indonesian Zakat Institutions (IZI) and examines the efficiency flaws of IZI. By employing the Data Envelopment Analysis (DEA) technique, the study proposes a solution to improve the efficiency of IZI.

\section{LITERATURE REVIEW}

A zakat institution is the institution responsible for managing the collection and distribution of zakat funds. The Quran describes the appointment of officials to collect and distribute zakat, which should be in the form of either a state department or a public fund managed entirely by a public body (Wahab, 2013: 2).

Hence, the state is responsible for collecting and distributing zakat in a wellorganized system as prescribed by Islam. Zakat also involves the Muslim society as a whole. Hence, certain ulama', like Imam Syafie, suggests that zakat must be paid to the authority (Buang, 2000:90).

Jahar (2010: 689) explains that in social sciences theory, social capital plays a pivotal role in philanthropic activity (zakat and sadaqah). Social capital, social networking and community involvement are important instruments for philanthropic activity, as they reinforces the idea that philanthropy is not merely an act of giving, but exists within the category of contribution, impelled by trust.

The Netherlands and Indonesia hold a similar position in terms of zakat and sadaqah payments. The payment is conducted through bank transfer. Moreover, donors and managers are not explicitly associated, as donations are anonymous. Donors can only acquire knowledge of the zakat institution's performance through the report and public information of the zakat institution (Jahar, 2010: 689).

Philanthropy management is not only due to the low credibility of public auditing, but it refers to the effectivity and efficiency of funds for programme objectives. It is particularly concerning that while donors are more concerned with the efficiency and objective of the programme, public auditing only provides 
finance-related information (Jahar, 2010: 689).

The effectivity and efficiency of zakat management is integral to achieving the zakat objective of alleviating.

\section{Concept of Efficiency in Islam}

Ali and Ascarya (2009: 113) explain the concept of reaching maximum potential from the Islamic perspective, and understand that it can be realised through hard work, whilst still maintaining balance. With this view, this paper will elaborate on the efficiency concept in Islam by presenting previous studies and explaining the input and output approaches of carrying out economic activities according to Islamic teachings. One of the inputs is based on aqidah (amantu billahi thummastaqim), the principle of having utility (khairunnasi anfauhum linnasi), and to be grateful of the achievement (man lam yashkurinnasa lam yashukurillaha), and not extravagance (israf) and squander (tabdhir) with the output.

The authors explain the concept of optimising input and output in accordance with the Qur'an and Hadith.

\section{a. Optimising Input}

Alharitsi (2003: 64) maintains that Muslim producers place a great deal of faith in Allah with respect to business outcomes and profits, as everything is predestined.

Ali and Ascarya (2009: 114) elucidate three main factors required to optimise the production input, as outlined below.

\section{Harnessing Natural Resources}

The Qur'an explains the role of a Muslim as a khalifah on earth. By this trusteeship, a Muslim must take care of the usage of natural resources to meet the needs of ummah. "And to Thamud [We sent] their brother Salih. He said, "O my people, worship Allah; you have no deity other than Him. He has produced you from the earth and settled you in it, so ask forgiveness of $\mathrm{Him}$ and then repent to Him. Indeed, my Lord is near and responsive."'” (Huud: 61).

\section{Equal and Fair Pay}

The Hadith of Rasulullah SAW emphasises that workers are entitled to relevant workers' rights. Abdullah ibn Umar reported: The Messenger of Allah, peace and blessings be upon him, said, "Pay the worker his wages before his sweat has dried." (Source: Ibn Majah 2443, Grade: Authentic (Shahih)).

\section{Prohibit the Practice of Usury}

The prohibition of riba is an attempt to improve wealth efficiency and eliminate interest, which would result in a lower production cost, thus improving efficiency (Ali and Ascarya, 2009: 114).

\section{b. Optimising Output}

An Islamic perspective of efficient employment practices relates to the following principles:

\section{Work Specialization and Division}

Specialization will shed light on the uniqueness and results on the professional expertise of the employees [see Alharitsi (2003: 93)]. Having employees perform specialized labor tasks can lead to increased productivity. Hence, division of labor enables increased efficiency, as it maximizes the employee's specific skill. Conversely, if the employee shifts from one task to another, efficiency might decrease.

\section{Avoiding Extravagance and Squander Production}


Al Mawardi, as cited in Ali and Ascarya (2009: 114), state that saraf is the fault of using the right dosage, whereas tabdzir is the fault of using the right allocation. Meanwhile, israf is concerned about spending, and is therefore related to consumption.

\section{Not Expropriating Others' Rights}

With respect to the property maintenance obligation, Islam also provides guidance on issues related to contract law or general rules for transactions. Islam prohibits all forms of injustice in economic activity. [Fauzia and Riadi (2014: 436)]

\section{The Benefits of Production}

In production activity, Islam considers the distribution of production benefits of among the greatest number of people and in the most equitable manner as paramount importance. It also encourages the avoidance of wasting production output, as stated in Surah Al-Mu'minuun: "And they who turn away from ill speech".

\section{The Values of Gratitude}

As narrated by Ahmad (2001), Abu Dawud and Tirmidzi, Abu Hurairah reports: "The Prophet, peace and blessings be upon him, said, 'He has not thanked Allah who has not thanked people'."

\section{Review on Previous Studies}

In 2009, Akbar published a study on the Management efficiency of 9 Zakat Organisations (OPZ) in Indonesia from 2005 to 2007 with 23 Decision-Making Unit (UPK). He employed DEA with a production approach. This research uses both output variables (pooled funds and channeled funds) and input variables (personnel costs, socialization costs and other operational costs). In stark contrast to 2006 and 2007, the efficiency of zakat institutions was better in 2005, with the technical, scale and overall efficiencies exceeding $71.27 \%$.

Wahab and Rahman (2012) conducted another study that related to Efficiency of Zakat Institutions in Malaysia: An Application of Data Envelopment Analysis (DEA). This research consisted of two input variables (total staff and total cost) and three output variables ( total of collection, total of distribution, and amount of muzakki). The results of his research indicate that zakat institutions have achieved an average technical efficiency of $80.6 \%$. It also reveals that pure technical inefficiency dominates the scale of inefficiency effects in determining the technical efficiency of zakat institutions in Malaysia.

Wahab and Rahman (2011) also have researched the Efficiency of Zakat Institutions and its Determinants. The analysists studied zakat institutions in Malaysia during 2003-2007 using a twostage method and data envelopment analysis. The input variables were number of employees and total cost, while the output variables included the amount of funds collected, the amount of funds who channeled and donors. They concluded that pure technical inefficiency over scale inefficiency is the cause of zakat institutions inefficiency. This could be due to the institutional inability to harness technology available to collect more zakat collection and distribute it to the recipients. Examination of the return to scale revealed that more than half of zakat institutions in Malaysia were scale inefficient (operating at DRS or IRS). The empirical findings suggest that the zakat payment system, the computerized zakat system, board size, audit committee and decentralization significantly affect efficiency of zakat institutions in Malaysia.

In examining the determinant of zakat institution efficiency in Indonesia and its productivity level, Parisi (2016) measured the efficiency and productivity 
level of Indonesian Zakat Institutions (IZI). This study aimed to deduce the factors that affect the efficiency level of IZI (DD, BAZNAS, PKPU, YBM BRI and RZ) with yearly data ranging from 2005 to 2014. This research employed Data Envelopment Analysis (DEA), Malmquist Productivity Index (MPI) and Tobit Regression. This study used two input variables (operational cost (X1) and socialization cost (X2)) and output variables (zakat collection funds (Y1) and fund distribution (Y2)) respectively. The findings signify that there were 5DMUs categorized as perfectly efficient (Constant Return to Scale), 10 DMUs categorized as "Increasing Return to Scale" and 12 DMUs categorized as "Decreasing Return to Scale". DD (2010) owned the OPZ with the lowest relative efficiency level (9.63\%). Moreover, about $80 \%$ of $5 \mathrm{OPZ}$ experienced an increase in productivity level. The researchers believe that the human resources variable negatively correlates with OPZ efficiency, while regulation and type of OPZ positively correlates with OPZ efficiency.

The next study we will review is on Determinants of Efficiency of Zakat Institutions in Malaysia: A Non-parametric Approach. This study consisted of two input variables (total staff and total cost) and three output variables (total aggregation, total distribution and number of muzakki). Wahab and Rahman (2013) found that the Total Factor Productivity (TFP) of zakat institutions in Malaysia increased at an average rate of 2.4 percent during the study period. They attributed this to technical progress rather than efficiency components. The empirical findings based on the Tobit regression suggest that the zakat payment system, the computerized zakat system, board size, audit committee and decentralization significantly affect the efficiency of zakat institutions in Malaysia.

Ahmad and Ma'in (2014) conducted a study titled: The Efficiency of zakat Collection and Distribution: Evidence from Two Stage Analysis. Four input variables were used ( number of amils, number of offices, number of bank agents, and cost of collection and distribution); and two output variables (zakat collected and zakat channeled). Their research explains that, firstly, both collection and distribution have lagging resources, or technical efficiency. Secondly, the result shows a lower efficiency of distribution than the collection function. Third, from the overall efficiency, allocative and cost efficiency scores demonstrate that maximum efficiency is achieved almost every year. It reveals that zakat institutions in Selangor are leveraging their input proportionately to ensure minimum cost incurred to produce a given output (amount collected and amount distributed) at a given input prices (cost collection and cost distribution).

\section{METHODOLOGY}

\section{Data}

Researchers used secondary data from the financial statements of each zakat institution. The object of this study is 15 out of 19 national zakat institutions during the period 2010 to 2016 with a total of 7 periods. Due to data limitations, the authors used a sample of 15 zakat institutions during the observation period. In total, this study used 58 DMU. This research uses DEA method with a production approach.

The input variables for the production approach are: 1) The number of amil; 2) The number of volunteers; 3) Personnel Cost; 4) Socialization Cost; 5) Operational Cost; and 6) The Number of ffices. The output variables of this study are: 1) The amount of zakat collected; 2) The distribution of consumptive zakat; 3) The distribution of productive zakat; 4) 
The number of muzakki; and 5) The number of mustahiq.

Table 1. Indonesian Zakat Institutions

\begin{tabular}{|c|c|c|}
\hline \multicolumn{3}{|c|}{ Indonesian Zakat Institutions } \\
\hline NO & $\begin{array}{c}\text { Indonesian Zakat Institutions with } \\
\text { community affiliation }\end{array}$ & $\begin{array}{c}\text { Indonesian Zakat Institutions without any } \\
\text { community affiliation }\end{array}$ \\
\hline 1 & Badan Amil Zakat Nasional & Baitul Maal Hidayatullah \\
\hline 2 & LAZIS NU & Rumah Zakat \\
\hline 3 & LAZISMU & Inisiatif Zakat Indonesia \\
\hline 4 & Dompet Peduli Umat Daaruttauhid & Dompet Dhuafa \\
\hline 5 & Al-Azhar Peduli Umat & Yatim Mandiri \\
\hline 6 & BAMUIS BNI & \\
\hline 7 & Baitul Maal Muamalat & Dana Sosial Al-Falah \\
\hline 8 & YBM BRI & Yayat \\
\hline
\end{tabular}

There are 8 IZI Mass on the left, and 7 IZI Non-Mass on the right.

\section{Operational Definition}

Researchers created an operational variable method by using input-output variable of production and intermediation approach. Under the production approach, an institution is a producer. Conversely, the intermediation approach assumes that a DMU acts as an intermediary. For the purpose of this study, the production approach is employed when defining the inputs and outputs, as it is assumed that zakat institutions are primarily producing zakat collection and zakat payers (in a way of dakwah, promotion etc.) and distributing the funds to the asnaf (beneficiaries). The production approach is more suitable for this study (Wahab, 2013: 115; \& Rahman, 2012). Table two represents the operational definition of the input and output variables of both the approach and the research:

Table 2. Input and Output Variables

\begin{tabular}{|c|c|}
\hline \multicolumn{2}{|c|}{ INPUT } \\
\hline $\mathrm{X}_{1}$ : The Number of Volunteers & $\begin{array}{l}\text { Volunteers: External Parties that assists in implementing work } \\
\text { programs at related zakat institutions. } \\
\text { The number of central and branch volunteers }\end{array}$ \\
\hline $\mathrm{X}_{2}$ : The Number of $\mathrm{Amil}$ & $\begin{array}{l}\text { Amil: Zakat managers organized in one agency or institution. } \\
\text { The number of Amil: Centre and branch offices }\end{array}$ \\
\hline $\mathrm{X}_{3}$ : Socialization Cost & Socialization Cost: Socialization Cost of Zakat Institutions \\
\hline $\mathrm{X}_{4}$ : Personnel Cost & Personnel Cost: Wage and Benefit of Amil \\
\hline $\mathrm{X}_{5}$ : Operational Cost & $\begin{array}{l}\text { Operational Cost: All distribution of } \mathrm{Amil} \text { funds in addition to } \\
\text { personnel costs, socialization, and the purchase of fixed assets }\end{array}$ \\
\hline $\mathrm{X}_{6}$ : The Number of Offices & The Number of All Offices (Centre and Branches) \\
\hline \multicolumn{2}{|r|}{ OUTPUT } \\
\hline $\mathrm{Y}_{1}$ : The Amount of Zakat Collected & Total amount of zakat collected \\
\hline $\begin{array}{l}\text { Y2: The Distribution of Consumptive } \\
\text { Zakat }\end{array}$ & Program of zakat consumptive distribution \\
\hline $\begin{array}{l}\text { Y}_{3}: \text { The Distribution of Productive } \\
\text { Zakat }\end{array}$ & Programm of zakat productive distribution \\
\hline
\end{tabular}

\section{METHODOLOGY}

The concept of efficiency is rooted in the microeconomic concept, namely, consumer theory and producer theory. Consumer theory tries to maximize utility or satisfaction from individual point of views, while producer theory tries to 
maximize profit or minimize costs from the producer's point of views. In the producer theory, the ' $S$ ' curved production frontier line describes the relationship between inputs and outputs of production process. This production frontier line represents the maximum output from the use of each input. It also represents the technology used by a business unit or industry. A business unit that operates on the production frontiers is technically efficient (Ascarya, 2017:6).

There are two components of efficiency from production theory (Farell, 1957: 1). Technical efficiency (TE) describes the ability of a business unit to maximize output given a specified input (efficiency in terms of quantity). Allocative efficiency (AE) describes the ability of a business unit to utilize inputs in optimal proportion based on their price (efficiency in terms of price). When combined, these efficiencies produce economic and cost efficiency, that is Overall Efficiency (OE). A company is economically efficient if it can minimize the production costs to produce certain output within common technology level and market price level.

Overall Efficiency (OE) = Allocative Efficiency (AE) x Technical Efficiency (TE). Technical Efficiency can be broken down into Pure Technical Efficiency (PTE) and scale efficiency (SE), so that Technical Efficiency $(\mathrm{TE})=$ Pure Technical Efficiency (PTE) x Scale Efficiency (SE). Therefore, $\mathrm{OE}=\mathrm{AE} \mathrm{x}$ PTE $x$ SE.

Efficiency can be measured using either a parametric approach or nonparametric approach. Parametric approaches can include stochastic frontier approach (SFA) and distribution free approach (DFA). Measuring efficiency using a non-stochastic approach, such as data envelopment analysis (DEA), tends to combine disturbance into inefficiency. DEA measures the efficiency of a decision-making unit (DMU) relative to other similar DMUs with the simple restrictions that all DMUs lie on or below the efficiency frontier. DEA can also determine how a DMU can improve its performance to become efficient. Nonstochastic approaches assume that random errors do not exist and that all deviations from the frontier indicate inefficiency. The advantage is that it does not require an a priori assumption about the analytical form of the production function so it imposes very little structure on the shape of the efficient frontier, so that there is no misspecification. The disadvantage is that it is sensitive to extreme observations and measurement error (the basic assumption is that random errors do not exist and that all deviations from the frontier indicate inefficiency), so there is a potential problem of "self-identifier" and "nearself-identifier".

DEA is a method for analyzing the relative efficiency and managerial performance of productive or decision making units (DMUs), that have the same multiple inputs and multiple outputs. DEA allows us to compare the relative efficiency of banks by determining the efficient banks as a benchmark and by measuring the inefficiencies in input combinations (slack variables) in other banks relative to the benchmark. DEA is a non-parametric, deterministic methodology for determining the relative efficient production frontier.

One can approach parametric or non-parametric efficiency measurement, of financial institutions such as banks based on their activities. There are three main approaches to explaining the relationship between input and output of banks. Production (or operational) and intermediation approaches apply the classical microeconomic theory of the firm. The modern (or assets) approach applies modified classical theory of the firm by incorporating some specificities 
of banks' activities, namely risk management and information processing, as well as some element of agency problems, which are crucial for explaining the role of financial intermediaries (Freixas and Rochet, 1998).

Production approach describes banking activities as the production of services to depositors and borrowers using all available factors of production, such as labor and physical capital. This approach views financial institutions as the producer of savings accounts and credit loans. Therefore, this approach defines input as workforce numbers, capital expenses on fixed assets and other materials, and defines output as the sum of all deposit accounts or other related transactions. This approach is appropriate for local branch level banks (Freixas and Rochet, 1998).

Intermediation approach describes banking activities as intermediaries charged with transforming the money borrowed from depositors (surplus spending units) into the money lent to borrowers (deficit spending units). In other words, deposits that are typically divisible, liquid, shortterm, and low-risk are transformed into loans that are typically indivisible, illiquid, long-term, and risky. This approach views financial institutions as intermediaries. These financial institutions transform and transfer financial assets from units with excess funds to units with lack of funds. Therefore, this approach defines input as financial capital (the deposits collected and the funds borrowed), and defines output as the volume of loans and investment outstanding. This approach is appropriate for main branch level banks (Freixas and Rochet, 1998).

\section{RESULTS AND ANALYSIS}

\section{Results}

Based on the analysis of 15 Indonesian Zakat Institutions (IZI), the study uncovered annual variations among IZI. However, efficiency measurements were still undertaken to examine the efficiency of IZI in terms of technical, pure technical and scale. The output approach was better suited for addressing the gap between the potential and realization of zakat collection.

Zakat management in Indonesia is efficient if its value reaches $100 \%$. If the number exceeds $100 \%$ or is close to $0 \%$, the management is assumed to be inefficient. The DEA methodology measures the relative efficiency. The subsequent paragraph presents the results of analysis with Banxia Frontier Analyst 3.2.2 and MAxDEA 6.1.

According to data analysis regarding the efficiency of IZI 38 zakat institutions of 58 DMU (65.51\%) are efficient in terms of technical, pure technical and scale. 10 IZI scored below $60 \%$, while the remaining 10 IZI have values above $60 \%$. Thus, one-third of IZI still need to improve their efficiency.

The DEA method can also measure and ensure a DMU is optimizing the level of production, that is, how the optimal use of inputs generates output. DMU has three states: Return to Scale (RTS), Increasing Return to Scale (IRS), Constant Return to Scale (CRS) and Decreasing Return to Scale (DRS).

The result shows that 10 of IZI are in the IRS condition, stated with 1 , and there are 10 IZI experiencing DRS condition, stated with -1 (see attachment 1). Overall, the IRS condition shows that zakat management is likely to continue to increase its output capacity by maintaining the available inputs. Addition of input is not effective in the above 
circumstances, because the resources used are still not functioning optimally. The condition of the DRS exhibits a lack of ideality in its input, which is required to hold input reductions.

\section{Efficiency of Indonesian Zakat Institutions: A Comparison}

To analyze the 15 IZI with different annual variations, DMU is divided into two groups: IZI Mass (BAZNAS, LAZISMU, LAZIS NU, Al-Azhar, DPU, BAMUIS BNI, YBM BRI, BMM) and IZI
Non-Mass (BMH, RZ, IZI, DD, YDSF, $\mathrm{NH}$, Yatim Mandiri). In the initial year of the study period, the technical efficiency of IZI Mass was relatively low (85.4\%). During 2013-2015, technical efficiency increased to $88.2 \%$, and reached $88.4 \%$ by 2016 (see Figure 3, left). IZI Non-Mass technical efficiency almost mirrored IZI Mass, where the initial technical efficiency during 2010-2012 was 86.3\%. IZI Mass then experienced a significant increase between 2013 and 2015 (91.7\%) and decreased to $88.1 \%$ in 2016 (see Figure 3, right).

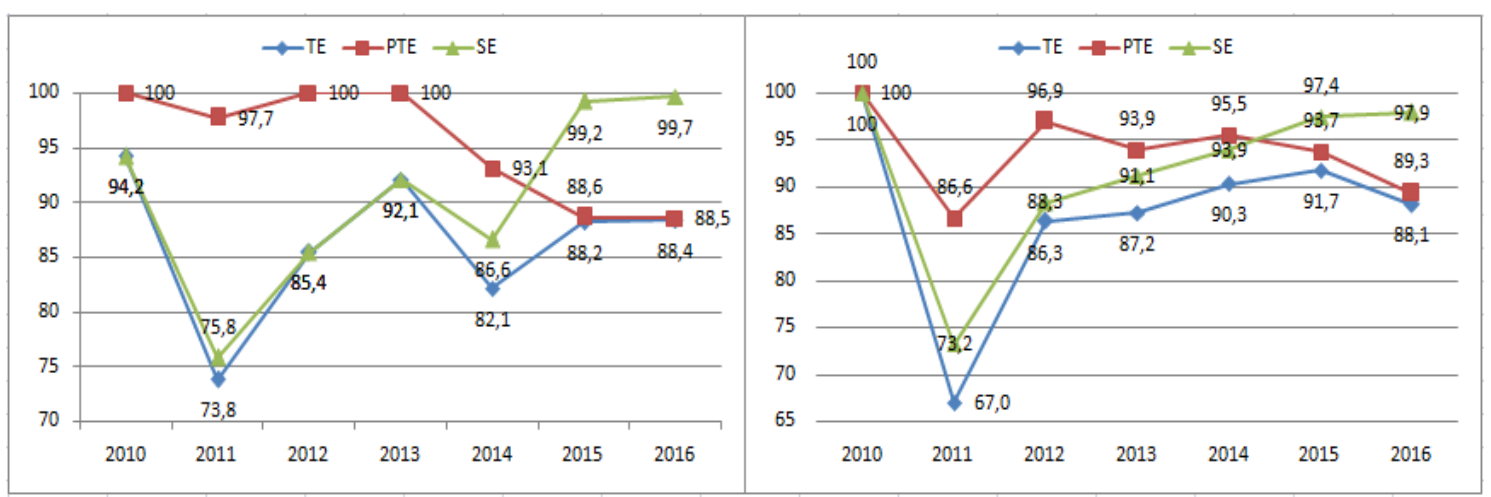

Figure 3. Efficiency of Indonesian Zakat Institutions Mass (Left) and Indonesian Zakat Institutions NonMass (Right)

The technical efficiency calculation of 8 IZI Mass witnessed a downward trend during the period of $2010-2016 \quad(94.2 \%$ to $88.4 \%)$. With respect to the technical subject of analysis, the most efficient IZI Mass is BAZNAS (2012-2016) and LAZISMU (2012-2016). The most inefficient zakat institution is LAZIS NU, with 4 years of inefficiency. However, LAZIS NU experienced an increase in 2016 with its efficiency level reaching 100\%. Another zakat institution that was proven inefficient is Al-Azhar, with 3 years of inefficiency (see Table 6, left). The technical efficiency calculation of 7 IZI Non-Mass shows an increase of efficiency from $67.0 \%$ in 2011 to $88.1 \%$ in 2016. In 2010, due to data limitation, only one zakat institution was suitable for analysis. The most efficient zakat institutions are YDSF, with 4 years of efficiency (2011-2014, 2015-2016) and $\mathrm{BMH}$ with 3 years of efficiency, excluding the year of 2014-2015. The most inefficient zakat institutions are Yatim Mandiri (2015-2016) and RZ, with 4 years of efficiency. However, RZ was efficient in 2010 and 2016 (see Table 6, right). 
Table 6. Technical Efficiency of Indonesian Zakat Institutions Mass (Left) and Indonesian Zakat Institutions Non-Mass (Right)

\begin{tabular}{|c|r|r|r|r|r|r|r|r|r|r|r|r|r|r|r|}
\hline TE & $\mathbf{2 0 1 0}$ & $\mathbf{2 0 1 1}$ & $\mathbf{2 0 1 2}$ & $\mathbf{2 0 1 3}$ & $\mathbf{2 0 1 4}$ & $\mathbf{2 0 1 5}$ & $\mathbf{2 0 1 6}$ & TE & $\mathbf{2 0 1 0}$ & $\mathbf{2 0 1 1}$ & $\mathbf{2 0 1 2}$ & $\mathbf{2 0 1 3}$ & $\mathbf{2 0 1 4}$ & $\mathbf{2 0 1 5}$ & $\mathbf{2 0 1 6}$ \\
\hline BAZNAS & 88,5 & 81,7 & 100 & 100 & 100 & 100 & 100 & BMH & & 100 & 100 & 100 & 89,8 & 95,1 & \\
\hline LAZIS NU & & 39,9 & 41,8 & 62,1 & 65,5 & & 100 & RZ & 100 & 34,0 & 59,1 & 49,0 & 61,9 & 100 & \\
\hline LAZISMU & 100 & 100 & 100 & 100 & 100 & & & IZI & & & & & & & 100 \\
\hline DPU DT & & & 100 & 90,9 & 72,8 & 100 & 100 & DD & & & & 100 & 100 & 100 & \\
\hline AL-AZHAR & & & & & 36,3 & 41,4 & 30,7 & YDSF & & & 100 & 100 & 100 & 98,8 & 100 \\
\hline BAMUIS BNI & & & & 100 & 100 & 100 & 100 & NH & & & & & 100 & 100 & 100 \\
\hline BMM & & & & & & 100 & 100 & Yatim Mandiri & & & & & & 56,4 & 52,7 \\
\hline YBM BRI & & & & 100 & 100 & & & & & & & & & & \\
\hline TE & $\mathbf{9 4 , 2}$ & $\mathbf{7 3 , 8}$ & $\mathbf{8 5 , 4}$ & $\mathbf{9 2 , 1}$ & $\mathbf{8 2 , 1}$ & $\mathbf{8 8 , 2}$ & $\mathbf{8 8 , 4}$ & TE & $\mathbf{1 0 0}$ & $\mathbf{6 7 , 0}$ & $\mathbf{8 6 , 3}$ & $\mathbf{8 7 , 2}$ & $\mathbf{9 0 , 3}$ & $\mathbf{9 1 , 7}$ & $\mathbf{8 8 , 1}$ \\
\hline
\end{tabular}

The pure technical efficiency level of 8 IZI Mass exhibited a downward trend. They declined considerably from $100 \%$ in 2010 to $88.5 \%$ in 2016. According to this measurement, the most efficient IZI Masses are BAZNAS, with 6 years of efficiency (except in 2011), followed by LAZISMU with 5 years of efficiency. The most inefficient IZI Mass is AlAzhar, which maintained its inefficiency streak for 3 consecutive years (see Table 7, left). Seve IZI Non-
Mass experienced an upward trend for pure technical efficiency, with an efficiency level increase from $86.6 \%$ in 2011 to $89.3 \%$ in 2016. Due to data limitation, only one zakat institution from 2010 was suitable for analysis. The most efficient zakat institutions are YDSF and BMH, as both experienced 5 years of efficiency. The most inefficient zakat institution is Yatim Mandiri (2015-2016) and RZ, with 4 years of efficiency. However, RZ was efficient in 2010 and 2016 (see Table 7, right).

Table 7. Pure Technical Efficiency of IZI Mass (Left) and IZI Non-Mass (Right)

\begin{tabular}{|c|c|c|c|c|c|c|c|c|c|c|c|c|c|c|c|c||}
\hline PTE & $\mathbf{2 0 1 0}$ & $\mathbf{2 0 1 1}$ & $\mathbf{2 0 1 2}$ & $\mathbf{2 0 1 3}$ & $\mathbf{2 0 1 4}$ & $\mathbf{2 0 1 5}$ & $\mathbf{2 0 1 6}$ & PTE & $\mathbf{2 0 1 0}$ & $\mathbf{2 0 1 1}$ & $\mathbf{2 0 1 2}$ & $\mathbf{2 0 1 3}$ & $\mathbf{2 0 1 4}$ & $\mathbf{2 0 1 5}$ & $\mathbf{2 0 1 6}$ \\
\hline BAZNAS & 100 & 93,2 & 100 & 100 & 100 & 100 & 100 & BMH & & 100 & 100 & 100 & 100 & 100 & \\
\hline LAZIS NU & & 100 & 100 & 100 & 100 & & 100 & RZ & 100 & 73,24 & 90,85 & 75,8 & 77,5 & 100 & \\
\hline LAZISMU & 100 & 100 & 100 & 100 & 100 & & & IZI & & & & & & & 100 \\
\hline DPU DT & & & & 100 & 81,65 & 100 & 100 & DD & & & & 100 & 100 & 100 & \\
\hline AL-AZHAR & & & & & 70,5 & 43,0 & 31,2 & YDSF & & & 100 & 100 & 100 & 100 & 100 \\
\hline BAMUIS BNI & & & & 100 & 100 & 100 & 100 & NH & & & & & 100 & 100 & 100 \\
\hline BMM & & & & & & 100 & 100 & Yatim Mandiri & & & & & & 62,2 & 57,6 \\
\hline YBM BRI & & & & 100 & 100 & 100 & & & & & & & & & & \\
\hline PTE & $\mathbf{1 0 0}$ & $\mathbf{9 7 , 7}$ & $\mathbf{1 0 0}$ & $\mathbf{1 0 0}$ & $\mathbf{9 3 , 1}$ & $\mathbf{8 8 , 6}$ & $\mathbf{8 8 , 5}$ & PTE & $\mathbf{1 0 0}$ & $\mathbf{8 6 , 6}$ & $\mathbf{9 6 , 9}$ & $\mathbf{9 3 , 9}$ & $\mathbf{9 5 , 5}$ & $\mathbf{9 3 , 7}$ & $\mathbf{8 9 , 3}$ \\
\hline
\end{tabular}

A similar pattern is also noted on the scale efficiency level of 8 IZI Non-Mass, whereby the efficiency level from 2010 to 2016 increased substantially by $5.5 \%$. The most efficient zakat institution is BAZNAS, with 5 years of efficiency (except in 2010-2011), followed by LAZISMU with 5 years efficiency. The most inefficient zakat institution is Al-Azhar, with 3 years of inefficiency (see Table 8 , left). There is a clear positive trend of scale efficiency level of 7 IZI Non-Mass during 2011-2016, where the efficiency level increased from $73.2 \%$ in 2011 to $97.9 \%$ in 2016. In 2010, due to data limitation, only one zakat institution was suitable for analysis. The most efficient zakat institution is YDSF, with 4 years of efficiency (except in 2015) and $\mathrm{BMH}$ with 3 years of efficiency, excluding the year of 2014-2015. The most inefficient zakat institution is Yatim Mandiri (2015-2016) and RZ, with 4 years of efficiency. However, RZ was efficient in 2010 and 2016 (see Table 8 , right). 
Table 8. Scale Efficiency of IZI Mass (Left) and IZI Non-Mass (Right).

\begin{tabular}{|c|c|c|c|c|c|c|c|c|c|c|c|c|c|c|c|c|}
\hline SE & $\mathbf{2 0 1 0}$ & $\mathbf{2 0 1 1}$ & $\mathbf{2 0 1 2}$ & $\mathbf{2 0 1 3}$ & $\mathbf{2 0 1 4}$ & $\mathbf{2 0 1 5}$ & $\mathbf{2 0 1 6}$ & SE & $\mathbf{2 0 1 0}$ & $\mathbf{2 0 1 1}$ & $\mathbf{2 0 1 2}$ & $\mathbf{2 0 1 3}$ & $\mathbf{2 0 1 4}$ & $\mathbf{2 0 1 5}$ & $\mathbf{2 0 1 6}$ \\
\hline BAZNAS & 88,5 & 87,8 & 100 & 100 & 100 & 100 & 100 & BMH & & 100 & 100 & 100 & 89,86 & 95,16 & \\
\hline LAZIS NU & & 39,9 & 41,8 & 62,2 & 65,5 & & 100 & RZ & 100 & 46,5 & 65,1 & 64,7 & 79,9 & 100 & \\
\hline LAZISMU & 100 & 100 & 100 & 100 & 100 & & & IZI & & & & & & & 100 \\
\hline DPU DT & & & & 91,0 & 89,2 & 100 & 100 & DD & & & & 100 & 100 & 100 & \\
\hline AL-AZHAR & & & & & 51,6 & 96,3 & 98,4 & YDSF & & & 100 & 100 & 100 & 98,89 & 100 \\
\hline BAMUIS BNI & & & & 100 & 100 & 100 & 100 & NH & & & & & 100 & 100 & 100 \\
\hline BMM & & & & & & 100 & 100 & Yatim Mandiri & & & & & & 90,67 & 91,68 \\
\hline YBM BRI & & & & 100 & 100 & 100 & & & & & & & & & \\
\hline SE & $\mathbf{9 4 , 2}$ & $\mathbf{7 5 , 8}$ & $\mathbf{8 5 , 4}$ & $\mathbf{9 2 , 1}$ & $\mathbf{8 6 , 6}$ & $\mathbf{9 9 , 2}$ & $\mathbf{9 9 , 7}$ & SE & $\mathbf{1 0 0}$ & $\mathbf{7 3 , 2}$ & $\mathbf{8 8 , 3}$ & $\mathbf{9 1 , 1}$ & $\mathbf{9 3 , 9}$ & $\mathbf{9 7 , 4}$ & $\mathbf{9 7 , 9}$ \\
\hline
\end{tabular}

Return to Scale value has three conditions that describe the condition of each DMU, including:

i. Increasing Return to Scale (IRS): The addition of 1 unit of input will result in the production of more than 1 unit of output. Therefore, the best strategy for the DMU is to continue to increase its production capacity;

ii. Constant Return to Scale (CRS): The addition of 1 unit of input will result in the addition of 1 unit of output. Thus, DMU must decrease its input; iii. Decreasing Return to Scale (DRS): The addition of 1unit of input will reduce 1 unit of output.

It is clear from the results that 8 IZI Mass CRS improved during 20102014, indicating that all IZI Mass have maximized their potential. On the other hand, 7 IZI Non-Mass CRS improved during 2010-2012, but appeared to stagnate during 2013-2015. In 2016, however, 5 IZI reached CRS and 1 IZI achieved DRS.

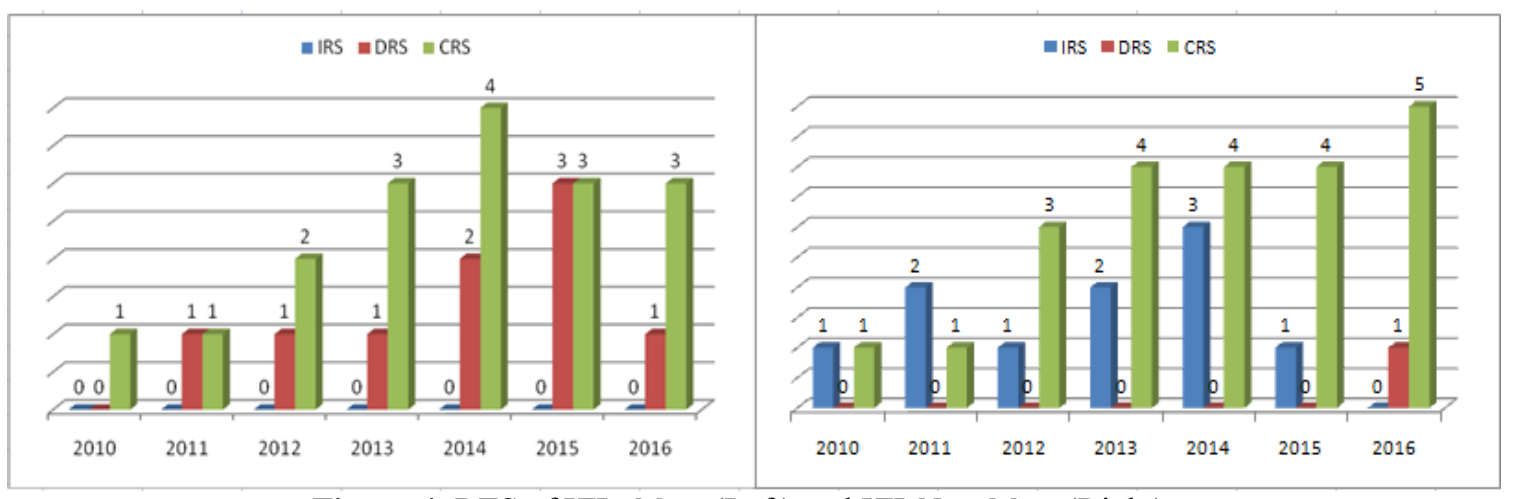

Figure 4. RTS of IZIs Mass (Left) and IZI Non-Mass (Right)

DMU is divided into two groups: Indonesian Zakat Institutions with community affiliations (IZI Mass), including BAZNAS, LAZISMU, LAZIS NU, Al-Azhar, DPU, BNUIS BNI, YBM BRI, and BMM; and Indonesian Zakat Institutions without any community affiliation (IZI NonMass), including BMH, RZ, IZI, DD,
YDSF, NH, and Yatim Mandiri. The number of amil, the number of volunteers and socialization costs are the main sources of IZI Mass inefficiency. For instance, during 20102012, IZI Mass had limited efficiency potential for several aspects: i) the number of amil, ii) the number of volunteers and operational costs, iii) 
socialization costs, iv) the amount of zakat collected, v) the distribution of productive zakat, and vi) the number of muzakki and mustahiq. However, in 2013-2016, the number of amil, the number of volunteers, socialization costs, operational costs and the distribution of consumptive zakat decreased (see Table 10).

Meanwhile, during 2010-2012, IZI Non-Mass experienced inefficiency in i) the number of muzakki, ii) the distribution of consumptive zakat and iii) personnel costs. In 2013-2016, i) the number of volunteers, ii) socialization costs, iii) personnel costs, iv) the amount of zakat collected and v) the distribution of consumptive zakat added to the inefficiency of IZI Non-Mass (see Table 10). Thus, IZI Non-Mass needs to reduce i) the number of amil, ii) the number of volunteers, iii) socialization costs, and iv) personnel cost and increase both the amount of zakat collected and the distribution of consumptive zakat.

Table 6. IZI Mass-min and IZI Mass max

\begin{tabular}{|l|c|c|c|c|c|c|c|}
\hline IZI Mass-min & $\mathbf{2 0 1 0}$ & $\mathbf{2 0 1 1}$ & $\mathbf{2 0 1 2}$ & $\mathbf{2 0 1 3}$ & $\mathbf{2 0 1 4}$ & $\mathbf{2 0 1 5}$ & $\mathbf{2 0 1 6}$ \\
\hline Number of Amil (X1) & -73 & -58 & -69 & -43 & -65 & -86 & -87 \\
\hline Number of Volunteers (X2) & -72 & -58 & -65 & -27 & -55 & -97 & -98 \\
\hline Socialization Cost (X3) & -75 & -60 & -58 & -52 & -60 & -89 & -93 \\
\hline Personnel Cost (X4) & -47 & -18 & -58 & -41 & -49 & -58 & -69 \\
\hline Operational Costs (X5) & -11 & -32 & -75 & -23 & -54 & -58 & -76 \\
\hline Number of Offices (X6) & 17 & -18 & -90 & -48 & -59 & -58 & -69 \\
\hline Amount of Zakat Collected (Y1) & 0.0 & 14 & 149 & 30 & 128 & 10 & 0.0 \\
\hline Distribution of Consumptive Zakat (Y2) & 0.0 & 0.0 & 516 & 1226 & 110 & 0.0 & 13 \\
\hline Distribution of Productive Zakat (Y3) & 169 & 82 & 0.0 & 0.0 & 18 & 5 & 0.0 \\
\hline Number of Muzakki (Y4) & 677 & 963 & 0.0 & 40 & 273105 & 21 & 0.0 \\
\hline Number of Mustahik (Y5) & 19 & 75 & 0.0 & 0.0 & 10,0 & 0.0 & 0.0 \\
\hline \multicolumn{1}{|c|}{ IZI mass-max $(X 1)$} & $\mathbf{2 0 1 0}$ & $\mathbf{2 0 1 1}$ & $\mathbf{2 0 1 2}$ & $\mathbf{2 0 1 3}$ & $\mathbf{2 0 1 4}$ & $\mathbf{2 0 1 5}$ & $\mathbf{2 0 1 6}$ \\
\hline Number of Amil & -70 & -49 & -26 & -34 & -46 & -67 & -60 \\
\hline Number of Volunteers (X2) & -69 & -48 & -18 & -12 & -52 & -94 & -93 \\
\hline Socialization Cost (X3) & -72 & -52 & 0.0 & $-43,5$ & -26 & -75 & -78 \\
\hline Personnel Cost (X4) & 0.0 & 0.0 & 0.0 & -39 & -33 & 0.0 & 0.0 \\
\hline Operational Costs (X5) & -40 & -17 & -41 & 0.0 & -33 & 0.0 & -22 \\
\hline Number of Offices (X6) & 0.0 & 0.0 & -77 & -78 & -79 & 0.0 & 0.0 \\
\hline Amount of Zakat Collected (Y1) & 32 & 40 & 496 & 82,5 & 224 & 167 & 225 \\
\hline Distribution of Consumptive Zakat (Y2) & 12 & 22 & 1373 & 709 & 195 & 141 & 268 \\
\hline Distribution of Productive Zakat (Y3) & 203 & 123 & 139 & 34,5 & 96 & 153 & 225 \\
\hline Number of Muzakki (Y4) & 778 & 1200 & 139 & 57 & 500666 & 193 & 225 \\
\hline Number of Mustahik (Y5) & 114 & 139 & 34,5 & 101 & 141 & 225 \\
\hline
\end{tabular}

Table 7. IZI Non Mass -Min and IZI Non Mass - max

\begin{tabular}{|l|c|c|c|c|c|c|c|}
\hline \multicolumn{1}{|c|}{ IZI Non-Mass min } & $\mathbf{2 0 1 0}$ & $\mathbf{2 0 1 1}$ & $\mathbf{2 0 1 2}$ & $\mathbf{2 0 1 3}$ & $\mathbf{2 0 1 4}$ & $\mathbf{2 0 1 5}$ & $\mathbf{2 0 1 6}$ \\
\hline Number of Amil (X1) & 0.0 & -75 & -40 & -51 & -24 & -29 & -76 \\
\hline Number of Volunteers (X2) & 0.0 & -74 & -40 & -51 & -31 & -30 & -80 \\
\hline Socialization Cost (X3) & 0.0 & -65 & -64 & -66 & -25 & -43 & -80 \\
\hline Personnel Cost (X4) & 0.0 & -67 & -48 & -50 & -38 & -32 & -68 \\
\hline Operational Costs (X5) & 0.0 & -65 & -40 & -50 & -54 & -33 & -47 \\
\hline Number of Offices (X6) & 0.0 & -65 & -40 & -50 & -24 & -21 & -47 \\
\hline Amount of Zakat Collected (Y1) & 0.0 & 7 & 0.0 & 0.0 & -2 & 80 & 88 \\
\hline Distribution of Consumptive Zakat (Y2) & 0.0 & 940 & 2289 & 474 & 101 & 455 & 493 \\
\hline
\end{tabular}




\begin{tabular}{|l|c|c|c|c|c|c|c|}
\hline Distribution of Productive Zakat (Y3) & 0.0 & 0.0 & 1036 & 651 & 0.0 & 0.0 & 0.0 \\
\hline Number of Muzakki (Y4) & 0.0 & 31 & 104 & 1 & 23 & 0.0 & 0.0 \\
\hline Number of Mustahik (Y5) & 0.0 & 0.0 & 0.0 & 0.0 & 0.0 & 0.0 & 0.0 \\
\hline \multicolumn{1}{|c|}{ IZI Non-Mass max } & $\mathbf{2 0 1 0}$ & $\mathbf{2 0 1 1}$ & $\mathbf{2 0 1 2}$ & $\mathbf{2 0 1 3}$ & $\mathbf{2 0 1 4}$ & $\mathbf{2 0 1 5}$ & $\mathbf{2 0 1 6}$ \\
\hline Number of Amil (X1) & 0.0 & -27 & 0.0 & 0.0 & 0.0 & -32 & -55 \\
\hline Number of Volunteers (X2) & 0.0 & -25 & 0.0 & 0.0 & -21 & -74 & -63 \\
\hline Socialization Cost (X3) & 0.0 & 0.0 & -40 & -32 & -1 & $-37,7$ & -62 \\
\hline Personnel Cost (X4) & 0.0 & -4 & -13 & 0.0 & -45 & -29 & -40 \\
\hline Operational Costs (X5) & 0.0 & 0.0 & 0.0 & 0.0 & -35 & -52 & 0.0 \\
\hline Number of Offices (X6) & 0.0 & 0.0 & 0.0 & 0.0 & 0.0 & -16 & 0.0 \\
\hline Amount of Zakat Collected (Y1) & 0.0 & 214 & 69 & 104 & 38 & 142,3 & 257 \\
\hline Distribution of Consumptive Zakat (Y2) & 0.0 & 2957 & 3941 & 1072 & 195 & 440 & 1023 \\
\hline Distribution of Productive Zakat (Y3) & 0.0 & 193 & 1822 & 1433 & 36 & 27,7 & 89 \\
\hline Number of Muzakki (Y4) & 0.0 & 285 & 245 & 106 & 55 & 27,7 & 89 \\
\hline Number of Mustahik (Y5) & 0.0 & 193 & 69 & 104 & 36 & 27,7 & 89 \\
\hline
\end{tabular}

\section{ANALYSIS}

From 2010 to 2013, the average technical efficiency of IZI Mass tended to be higher than IZI Non-Mass. Whereas in 2014, IZI Non-Mass efficiency increased from $87.2 \%$ to $90.3 \%$ and IZI Non-Mass efficiency decreased from $92.1 \%$ to $82.1 \%$. Regarding pure technical efficiency during 2011-2013, IZI Mass efficiency increased from $97.7 \%$ to $100 \%$ and experienced a downward trend in 2014$2016(88.5 \%)$. In contrast, IZI NonMass pure technical efficiency fluctuated during 2011-2016. In 2012, it increased by $10.3 \%$ from the previous year. It then began fluctuating until 2016.

IZI Mass scale efficiency fluctuated during 2010-2013, decreasing in $2014(86.6 \%)$ and subsequently reaching its highest level during 20152016 (99.7\%). IZI Non-Mass scale efficiency fluctuated during 2010-2012, and then stabilized until 2016.

IZI Mass was consistently inefficient in The Number of Amil (X1), The Number of Volunteers (X2) and Socialization Costs (X3) during the research period, except in 2012. This impelled high operational costs in every year except in 2013 and 2015. The amount of zakat collected (Y1) was inefficient in every year except 2010 and 2016, indicating the need for an increase in the amount of zakat collected.

IZI Non-Mass were consistently inefficient in the number of volunteers (X2), socialization costs (X3) and the distribution of consumptive zakat (Y3). The number of mustahiq (Y5) showed promising results, indicating that IZI Non-Mass fulfilled their intermediate function.

In 2010-2011, of 8 IZI NonMass, $12.5 \%$ reached the Return to Scale (CRS) level. The positive trend continued by reaching $37.5 \%$ in 2012 , $50 \%$ during 2013-2015, and $62.5 \%$ in 2016. IZI Non-Mass CRS levels increased from $14.3 \%$ in 2011 to $28.6 \%$ in 2012 and reached $42.8 \%$ in 2016.

The 2016 efficiency rate of IZI Mass and IZI Non-Mass reflect that both zakat institutions have achieved technical efficiency. Meanwhile, improvement of IZI Non-Mass efficiency could occur by reducing the number of amil (X1), the number of volunteers (X2) and the socialization costs (X3), as well as increasing the amount of zakat collected (Y1). On the other hand, IZI Non-Mass inefficiency could be lowered by reducing the 
socialization costs (X3), personnel costs (X4), as well as increasing the distribution of consumptive zakat (Y2).

The comparative analysis of IZI Mass and IZI Non-Mass reveal that the main issues that explain the inefficiency of zakat institutions are i) socialization costs, ii) the number of volunteers, iii) the amount of zakat collected, and iv) the distribution of consumptive zakat, reducing the intermediation function of zakat institutions.

Zakat institutions that developed and expanded in the corporate environment (banking) tend to be more efficient than zakat institutions such as BAMUIS BNI, BMM, and YBM BRI. The rationale underlying this phenomenon may be the salary deduction system, which reduces the pressure to collect ZIS funds.

The list below shows Indonesian Zakat institutions (IZI) that steadily improve their level of efficiency from year to year:

a. Baitul Maal Ummah Islam BNI (BAMUIS BNI) [2013-2016]

b. Nurul Hayat [2014-2016]

c. Dompet Dhuafa (DD) [20132015]

d. LAZISMU[2010-2014]

e. Yayasan Baitul Maal BRI (YBM BRI)[2012-2014]

f. Baitul Maal Muamalat (BMM) [2015-2016]

\section{CONCLUSIONS AND RECOMENDATIONS}

\section{Conclusions}

Zakat institutions (IZI Mass and IZI Non-Mass) play a pivotal role in zakat collection in Indonesia by maximizing particular inputs and outputs. Therefore, zakat institutions must be effective, efficient, socialized, and produce enormous impacts on alleviating poverty and improving the prosperity of zakat recipients. The subsequent paragraph presents the research findings.

The technical calculation demonstrates that $65.51 \%$ of IZI (38 of 58 DMUs) are efficient, with 100\% score. While $24.13 \%$ scored between $50-99 \%$ and $6.89 \%$ scored below 50\%. The pure technical calculation reveals that $81.03 \%$ of IZI (47 of 58 DMUs) are efficient, with $100 \%$ score. $15.51 \%$ scored between $50-99 \%$ and $3.44 \%$ scored below $50 \%$, while calculations on a scale basis show that $65.51 \%$ of IZI (38 of 58 DMU) are at an efficient point with a score of $100 \% .29 .31 \%$ of IZI scored between 50-99\% and 5.17\% scored below $50 \%$.

\section{Recommendations}

Based on the research findings, the authors propose several recommendations:

1. Indonesian Zakat Institutions:

1) Both government and private IZI should issue annual reports in an effort to improve transparency and accountability in the management of ZIS funds. The financial statements of IZI will be useful for academics, students and researchers to improve the development of zakat in Indonesia.

2) IZI must optimize the distribution of zakat fund to asnaf to meet the objectives of decreasing the poverty rate.

3) To increase the number of muzakki, amount of zakat collected, the distribution of consumptive zakat, and to reduce the cost of socialization and the number of 
volunteers to improve the efficiency of the management of IZI.

2. Government:

To make accounting standards for zakat institutions and legalize it to make it

\section{REFERENCES}

Ahmad, I.H.J., Main, M. (2014). The Efficiency of Zakat Collection and Distribution Evidence From Two Stage Analysis, Journal of Economic Cooperation and Development, Vol. 35,3, pp. 133-170.

Ahmad, A.A. (2001). Musnad Imam Ahmad bin Hanbal. Muassisu arRisalah. Turki.

Al-Haritsi, A.B.J. (2003). Al-Fiqh AlIqtishad li Amiril Mukminin Umar Ibn Al-Khathtab. Jeddah Saudi Arabia. Al-Andalus AlKhadra.

Akbar, N. (2009) Analisis Efisiensi Pengelola Zakat Nasional Dengan Pendekatan Data Envelopment Analysis. TAZKIA Islamic Finance and Business Review, Vol. 4, No. 2, pp. 760784.

Ali, M.M., dan Ascarya. (2009). Analisis Efisiensi Baitul Maal Wat Tamwil Dengan Pendekatan Two Stage Data Envelopment Analysis (Studi Kasis Kantor Cabang BMT MMU dan BMT UGT Sidogiri). TAZKIA Islamic Finance and Business Review, Vol. 5, No. 2, pp. 110-125.

Ascaya. (2017). Comparing the Technical Efficiency of Leading Baitul Maal wat Tamwil and Conventional Cooveratives in Indonesia. Paper, presented at 11th Internasional Conference easier for academics, communities, and related zakat institutions to obtain information that would meliorate the accountability and transparency of zakat management in Indonesia.

Bulletin of Monetary Economics and Banking, Jakarta, Indonesia, August 24, 2017.

Banker, R.D., Charnes, A., dan Cooper, W.W. (1984). Some Models for Estimating Technical and Scale Inefficiencies in Data Envelopment Analysis. Management Science, Vol.30 No.9, pp. 1078-92.

Bauer, P.W., Berger, A.N., Ferrier, G.D., dan Humphrey, D.B. (1998). Consistency Conditions for Regulatory Analysis of Financial Institutions: A Comparison of Frontier Efficiency Methods, Financial Services Working Paper, 02/97, The Federal Reserve.

Beik,I.S., Nursechafia, Muljawan, D., Yumanita, D., Fiona, A., Nazar, J.K. (2014).Towardss an Establishment of an Efficient and Sound Zakat System: Proposed Core Principles for Effective Zakat Supervision.Paper Presented in the Working Group of Zakat Core Principles. pp. 3-43. Jakarta: BAZNAS dan BI.

Buang, A.H. (2000). Pengurusan Zakat: Satu Analisis dari Perspektif AlQur'an dan al-Sunnah, Jurnal Syariah, Vol. 8:2, pp. 89-102.

Charnes, A., Cooper, W.W., dan Rhodes, E. (1978). Measuring The Efficiency of Decision Making Units, European Journal of Operation Research, Vol. 2, pp. 429-44. 
Coelli, T.J., Rao, D.S.P., O’Donnell, C.J., dan Battese, G.E. (2005). Introduction to Efficiency and Productivity Analysis, Second Edition, Kluwer Academic Publishers, Boston.

Deprins, D., Simar, L., dan Tulkens, H. (1984). Measuring Labor Efficiency In Post Offices, In Marchand, M., Pestiau, P., Dan Tulkens, H. (Eds), The Performance of Public Enterprises: Concepts and Measurements,Holland, Amsterdam.

Farrell, M.J. (1957). The Measurement of Productive Efficiency, Journal of The Royal Statistical Society, Vol.120, No.3, 253-90.

Fauzia, Y.I., dan Riadi, K.A. (2014). Prinsip Dasar Ekonomi Islam Perspektif Maqoshid AlSyariah. Jakarta. Prenadamedia Group.

Freixas, X. dan Rochet, J.C. (1997). Microeconomics of Banking, MIT Press Books, The MIT Press, Edition 1, Vol. 1.

Jahar, A.S. (2010, November), Masa Depan Filantropi Islam Indonesia Kajian Lembagambaga Zakat dan Wakaf. Paper dipresentasikan di Annual Conference on Islamic Studies (ACIS) ke-10 di Banjarmasin.

Lessy, Z. (2009). Zakat (Alms-Giving) Management In Indonesia: Whose Job Should It Be? LaRiba Jurnal Ekonomi Islam, Vol.3, No.1, 106-119.

Parisi, S. (Juni 2016), Analisis Determinan Efisiensi Lembaga Zakat di Indonesia dan Tingkat Produktivitasnya, Paper dipresentasikan di Forum Riset Ekonomi dan Keuangan Syariah XIV, Kumpulan Riset Terbaik. pp. 33-54. Padang: OJK-IAEIIAIN Imam Bonjol.

PUSKAS BAZNAS. (2017). Outlook Zakat Indonesia 2017, diterbitkanoleh Pusat Kajian Strategis BAZNAS (Puskas BAZNAS).

Ramanathan, R., (2003). An Introduction to Data Envelopment Analysis, New Delhi, Sage Publication, India.

Sharma, D., Sharma, A.K., Barua, M.K. (2012). Efficiency and Productivity of Banking SectorA Critical Analysis of Literature and Design of Conceptual Model. Qualitative Research in Financial Markets, Vol. 5 No. 2.

Wahab, N. ABD., (2013). Efficiency and Governance of Zakat Institution in Malaysia, A thesis submitted in fulfilment of the requirements for the degree of Doctor of Philosophy of Islamic Banking and Finance, Institute of Islamic Banking and Finance International Islamic University Malaysia.

Wahab, ABD. N., dan Rahman, A. R. A . (2011). Efficiency of Zakat Institutions and Its Determinants. Paper dipresentasikan di $8^{\text {th }}$ International Conference on Islamic Economics and Finance. pp. 1-19. Center For Islamic Economic and Finance: Qatar Foundation.

Wahab, ABD. N., dan Rahman, A . R . A . (2012). Efficiency of Zakat Institution In Malaysia: An Application of Data Envelopment Analysis, Journal of Economic Cooperation and Development, Vol. 33,1, pp. 95112.

Wahab, ABD. N., dan Rahman, A . R . A . (2013). Determinants of Efficiency of Zakat Institutions in Malaysia: A Non- 
Parametric Approach, Asian

Journal of Business and Accounting, Vol. 6,2, pp. 33-74.

Solahuddin Al-Ayubi

STEI TAZKIA

solahuddin.gontor@gmail.com

Ascarya

Central Bank of Indonesia

ascarya@yahoo.com

Bayu Taufiq Possumah

STEI TAZKIA 
Appendix

Appendix 1. Level of Efficiency in Zakat Management

\begin{tabular}{|c|c|c|c|c|c|}
\hline NO & Unit Name & TE & PTE & SE & RTS \\
\hline 1 & 2010-LAZISMU & 100 & 100 & 100 & 0 \\
\hline 2 & 2010-Rumah Zakat & 100 & 100 & 100 & 0 \\
\hline 3 & 2011-Baitul Maal Hidayatullah & 100 & 100 & 100 & 0 \\
\hline 4 & 2011-LAZISMU & 100 & 100 & 100 & 0 \\
\hline 5 & 2012-BAZNAS & 100 & 100 & 100 & 0 \\
\hline 6 & 2012-Baitul Maal Hidayatullah & 100 & 100 & 100 & 0 \\
\hline 7 & 2012-LAZISMU & 100 & 100 & 100 & 0 \\
\hline 8 & 2012-Yayasan Baitul Maal BRI & 100 & 100 & 100 & 0 \\
\hline 9 & 2012-Yayasan Dana Sosial Al-Falah & 100 & 100 & 100 & 0 \\
\hline 10 & 2013-Baitul Maal Umat Islam BNI & 100 & 100 & 100 & 0 \\
\hline 11 & 2013-BAZNAS & 100 & 100 & 100 & 0 \\
\hline 12 & 2013-Baitul Maal Hidayatullah & 100 & 100 & 100 & 0 \\
\hline 13 & 2013-Dompet Dhuafa & 100 & 100 & 100 & 0 \\
\hline 14 & 2013-LAZISMU & 100 & 100 & 100 & 0 \\
\hline 15 & 2013-Yayasan Baitul Maal BRI & 100 & 100 & 100 & 0 \\
\hline 16 & 2013-Yayasan Dana Sosial Al-Falah & 100 & 100 & 100 & 0 \\
\hline 17 & 2014-Baitul Maal Umat Islam BNI & 100 & 100 & 100 & 0 \\
\hline 18 & 2014-BAZNAS & 100 & 100 & 100 & 0 \\
\hline 19 & 2014-Dompet Dhuafa & 100 & 100 & 100 & 0 \\
\hline 20 & 2014-Nurul Hayat & 100 & 100 & 100 & 0 \\
\hline 21 & 2014-LAZISMU & 100 & 100 & 100 & 0 \\
\hline 22 & 2014-Yayasan Baitul Maal BRI & 100 & 100 & 100 & 0 \\
\hline 23 & 2014-Yayasan Dana Sosial Al-Falah & 100 & 100 & 100 & 0 \\
\hline 24 & 2015-Baitul Maal Umat Islam BNI & 100 & 100 & 100 & 0 \\
\hline 25 & 2015-BAZNAS & 100 & 100 & 100 & 0 \\
\hline 26 & 2015-Baitul Maal Muamalat & 100 & 100 & 100 & 0 \\
\hline 27 & 2015-Dompet Dhuafa & 100 & 100 & 100 & 0 \\
\hline 28 & 2015-Dompet Peduli Umat & 100 & 100 & 100 & 0 \\
\hline 29 & 2015-Nurul Hayat & 100 & 100 & 100 & 0 \\
\hline 30 & 2015-Rumah Zakat & 100 & 100 & 100 & 0 \\
\hline 31 & 2016-Baitul Maal Umat Islam BNI & 100 & 100 & 100 & 0 \\
\hline 32 & 2016-BAZNAS & 100 & 100 & 100 & 0 \\
\hline 33 & 2016-Baitul Maal Muamalat & 100 & 100 & 100 & 0 \\
\hline 34 & 2016-Dompet Peduli Umat & 100 & 100 & 100 & 0 \\
\hline 35 & 2016-LAZ IZI & 100 & 100 & 100 & 0 \\
\hline 36 & 2016-Nurul Hayat & 100 & 100 & 100 & 0 \\
\hline 37 & 2016-LAZIS NU & 100 & 100 & 100 & 0 \\
\hline 38 & 2016-Yayasan Dana Sosial Al-Falah & 100 & 100 & 100 & 0 \\
\hline
\end{tabular}




\begin{tabular}{|c|c|c|c|c|c|}
\hline 39 & 2015-Yayasan Dana Sosial Al-Falah & 98,89 & 100 & 98,89 & -1 \\
\hline 40 & 2015-Baitul Maal Hidayatullah & 95,16 & 100 & 95,16 & -1 \\
\hline 41 & 2013-Dompet Peduli Umat & 90,98 & 100 & 90,98 & 1 \\
\hline 42 & 2014-Baitul Maal Hidayatullah & 89,86 & 100 & 89,86 & -1 \\
\hline 43 & 2010-BAZNAS & 88,53 & 100 & 88,53 & 1 \\
\hline 44 & 2011-BAZNAS & 81,76 & 93,16 & 87,76 & 1 \\
\hline 45 & 2014-Dompet Peduli Umat & 72,85 & 81,65 & 89,22 & 1 \\
\hline 46 & 2014-LAZIS NU & 65,51 & 100 & 65,51 & 1 \\
\hline 47 & 2013-LAZIS NU & 62,19 & 100 & 62,19 & 1 \\
\hline 48 & 2014-Rumah Zakat & 61,98 & 77,53 & 79,93 & -1 \\
\hline 49 & 2012-Rumah Zakat & 59,12 & 90,85 & 65,07 & -1 \\
\hline 50 & 2015-Yatim Mandiri & 56,40 & 62,20 & 90,67 & -1 \\
\hline 51 & 2016-Yatim Mandiri & 52,78 & 57,57 & 91,68 & -1 \\
\hline 52 & 2013-Rumah Zakat & 49,00 & 75,78 & 64,66 & -1 \\
\hline 53 & 2012-LAZIS NU & 41,82 & 100 & 41,82 & 1 \\
\hline 54 & 2015 Al-Azhar & 41,46 & 43,04 & 96,33 & 1 \\
\hline 55 & 2011-LAZIS NU & 39,91 & 100 & 39,91 & 1 \\
\hline 56 & 2014 Al-Azhar & 36,36 & 70,52 & 51,56 & 1 \\
\hline 57 & 2011-Rumah Zakat & 34,04 & 73,24 & 46,47 & -1 \\
\hline 58 & 2016 Al-Azhar & 30,72 & 31,21 & 98,43 & -1 \\
\hline \multicolumn{2}{|c|}{ Average } & 87,06 & 94,08 & 91,98 & \\
\hline
\end{tabular}

Source: Processed from Software Banxia Frontier Analyst 3 